\title{
南洋の桃太郎
}

一一話、植民地政策、パロディ

Robert TIERNEY(ロバート・ティアニー: Professor of modern Japanese literature and Head of the East Asian Literatures and Cultures Department, University of Illinois at Urbana-Champaign)

四 rtierney@illinois.edu

(アメリカ)イリノイ大学東アジア言語文化学科教授。Robert Tierney is a professor and head of the East Asian Literature and Culture Department at the University of llinois at Urbana-Champaign. His reœent publications include Monster of the Twentieth Century: Kötoku Shüsui and Japan's First Anti-Imperialist Movement (University of California Press. 2015): "Othello in Tokyo : Performing Race and Empire in Early Twentieth Century Japan." Shakespeare Quarterly 62 (4). December 2011: and Tropics of Savagery : the Culture of Japanese Empire in a Comparative Frame (Uhiversity of California Press. 2010). He is currently working on a translation of Nakae Chōmin's One Year and a Half and a study of writings on death in the Meiji period.

\section{Momotarō in the South Seas : Folklore, Colonial Policy Studies, and Parody}

Momotarō became a fixture in the education of Japanese elementary school pupils during the early Meiji period. In the early $20^{\text {th }}$ century, his journey to the ogre island was often conflated with Japan's advance toward the South Seas. In this article, I compare two rewritings of the folktale : Nitobe Inazō's essay "The Folktale Momotarō" (1907) and Akutagawa Ryūnosuke’s story "Momotarō" (1925). Nitobe, Japan's first professor of colonial policy studies, treated the tale of Momotarō as a pedagogical tool that could fire the imagination of insular Japanese youth, enabling them to look beyond the confines of the Japanese archipelago. By contrast, Akutagawa focalized his retelling of the folktale by adopting the point of view of humanized ogres living peacefully on an island paradise in the South Seas. In this iconoclastic version, Momotarō is portrayed as a cruel invader who plunders the island and reduces its inhabitants to slavery. At the intersection of folklore, propaganda and parody, Momotarō emerges as an embodiment of the defining of self and other in the age of empire.

Keywords Momotarō(桃太郎), Folklore(民俗学), Parody(パロディー), Propaganda (プロパガンダ), Colonial Policy Studies(植民政策研究) 
1945年に製作された「桃太郎：海の神兵」は高く評価されている初期日本アニメであ る。と同時にそのアニメはプロパガンダ映画と見なされ、GHQにより焼却されたが、 1982年に松竹の倉庫で奇跡的に残されたコピーが発見された。驚くことに、このアニメ では、桃太郎の鬼ヶ島ゆきを侵略戦争に作り替え、桃太郎の主人公は日本海軍大将にな り、鬼は「鬼畜英米」になる。桃太郎の民話の動物の家来たちは犬、猿、雉子意外に、熊 や兔なども加え、又このアニメではたくさんの南洋の動物達が桃太郎の味方の役割を果 たしている。「桃太郎：海の神兵」は 海軍のマレー半島奇襲作戦を題材としたもので、 日本海軍の協力のもとで監督瀬尾光世によって作られたものである。瀬尾光代は敵国で あるアメリカのディズニーの「ファンタジア」の影響を強く受け、このアニメ、「桃太 郎：海の神兵」を子供達に夢と希望を与える作品にしようとした。その一方で、アジア 解放、大東亜共栄圏を賛美する国策映画でもる。この論文では桃太郎がどのようにして 帝国日本人のシンボルとなったか、又鬼ヶ島が東南アジア、つまり、「南洋」と「南進論」 と繋がりを持つようになったか、その歴史的背景を明らかにする試みである。

\section{1 南進論の発展史}

19世紀の後半より多くの作家は、日本は南洋との貿易関係を拡大すべきだと呼び掛け ていた。当時の南洋は、西洋の帝国主義諸国に支配されてきた地域であった。20世紀初 めから、交易関係から征服や国家の領土拡張という、より攻撃的な目標へと変化した。 清水眥氏は、この時期の「出版物やステレオタイプやスローガンのとめどない汇濫」が 「南方への進出に賛同する明々白々なムード(南進論)、つまりは南洋熱の発生」をもたら したと記している゙。これらの「ステレオタイプやスローガン」は、突然にどこからとも なく現われたわけではなく、むしろそれらは日本帝国の南洋への大規模な進出に伴って 現われた。日清戦争の後、台湾は日本の最初の植民地となり、また1914年に、日本はド イツの統治下にあったミクロネシアの島々を占領し、後に国際連盟委任統治領として支 配した。第一次世界大戦下、ヨーロッパとその植民地の間の貿易が途絶えた時期に、日 本の商社はその機を捉え、東南アジア全域にわたって交易と投資を拡大した。

日本本土では、1914年の東京大正博覧会により、南洋に対する人々の意識が否応なし に高まった。この 博覧会では、史上初めて 南洋のパビリオンが呼び物とされ、そこに は熱帯の物産の展示や、「喰い人種」[作者註記「人食い人種」に対する当時の呼称をを目玉 にした人間を見世物にする展示がひしめいていた。これらの人食い人種が「実際に接す ると「如何にも従順」であり、人食いといっても過去のこと」だったと記していた。に

1 Shimizu Hajime. "Nanshin-ron: Its Turning Point in World War I" in The Developing Economies XXV-4, December 1987, p.388.

2 『実業之日本』1914年。土屋忍「文学における土人：中川陽一と村上龍」『戦後という制度』, インパクト出版, 2002), pp.75-254での引用。 
もかかわらず、従順にしているとはいえ、生きた人食い人種の展示は、多くの観客をパ ビリオンに集めただけではなく、彼らが原始的に南洋島民について抱いていたステレ オタイプを強化する役目を果たしもした。

南洋へのこうした心酔は、20世紀初頭の日本小説の数々の代表作の中に垣間見られ る。田山花袋の1907年の小説『蒲団』の主人公・竹中時雄は、作家を志す女弟子・芳子へ の恋慕の情から逃れるために、「㸘そ南洋の植民地に漂泊しよう」と萝想する。夏目漱 石の1912年の小説『彼岸過迄』の主人公・田川敬太郎は、児玉堷耘のボルネオ冒険談 ${ }^{4}$ 熱 心に読み、自分が護謨㷊の栽培監督者になって、「果しのない広野を埋め尽寸勢いで何 百万本といら護謨の樹が茂っている真中に、一階建のバンガローを拵えて」5いるのを想 像する。当時はマレーはゴムの原料の有名な生産地のため、自動車産業の成長で、タイ ヤに使うゴムの需要が爆発的に増え、仕事を求めて世界中の人々がマレーに進出した。 この小説で、漱石は日本の南進によって、青年の想像する未来像をどのようにして形づ くっていることを示す。又志賀直哉は、1921年から1937年にかけて『改造に連載した 『暗夜行路』で、日本国内の人々の日常生活の中にあるスペクタクルとして南洋を描き出 す。この小説中で、主人公・時任謙作の友人の青年・宮本は、土人の踊りを見に、前述 の南洋館を何度か訪れている6 ${ }^{6}$ 。最後にもう一つだけ例を挙げるなら、谷崎潤一郎は 1910年、彼がまだ青年の頃に、『象』といら一幕劇を発表する。この劇は、インドと中国 の間にある東南アジアのさる王国から送られた象を引き連れた行列に対する、江戸庶民 の反応を描いたものである。この作品は、徳川時代(1600-1867年)の初期を舞台とした ものだが、また20世紀初期の南進論の言説の戯文でもある。

四版をふんだんに盛り込んだ鶴見祐輔の『南洋遊記』は、南進論の著作の極致を示して いる。鶴見はこの作品の序文で、日本の青少年の間に帝国主義を支える感情的な傾向を 培うよう作家たちを促している。南洋における日本の帝国主義の企ての成功は、「国民 の主観的な態度」マにかかっている、と彼は力説する。

今や我国に於て南進論の声は漸く旺であつて、…甚だ慶すべき事であるけれ共、 単に殖産、移民と言ふ如き理知より来る、南進策のみでは未だ充分であり、完壁で あると、自分は考へる事が出来ないのである。更に、南国に対する興味と憧憬とを 刺戟するので無ければ、我々が意を安んじて、墳墓の地と為す丈の心構へは起つて 来まいと思ふのである。…而して、此の一味憧憬慕望の情の湧くのは、空想の旺な 直覚力の鋭い少年時代、青年時代であらうと、自分は思ふのである。…帝国主義は

3 田山花袋「蒲団」(『田山花袋全集』第一巻, 文泉堂書店, 1973), p.548.

4 児玉音松は、20世紀初期に南洋を旅した探検家であった。彼の著作『南洋』は当初、漱石の小説と同じ年、 1912年に東京朝日新聞への連載として世に出た。

5 夏目漱石『彼岸過迄』(新潮文庫. 1952), pp.16-18を参照。

6 志賀の小説は1921年に連載を開始したが、この箇所で述べられていることはおそらく、1914年の東京大正 博覧会を指している。志賀直哉『暗夜行路』(岩波文庫, 1976), p.187.

7 鶴見祐輔『南洋遊記』(大日本雄弁会, 1917), 序, p.5. 
摇籃の中に在る、少年の夢に通ふ、異郷外域の風光は、之れ軈、日本民族膨張の礎石 と為るのである ${ }^{8}$ 。

[訳者註記『南洋遊記』からの以上二つの引用箇所では旧字を新字に改めた。]

日本の「開国」とは、外国人が日本にやってくることができるのを意味しただけでは なく、日本人が海外に行って定住できることも意味していた。ただ鶴見は、実際問題と して、ほとんどの日本人は「父祖伝来の地」を捨てるのに抵抗を感じ、純粋に知的な議論 によってこの抵抗を克服することはできないだろう、と認めている。人々が海外に移 住できるようにするには、彼らの中に異郷の地への欲求を掻き立てるよう手を加えなけ ればならない。逆に、「異郷への憧憬」を誘うために、作家は読者の想像力に訴えなけれ ばならない。最後に肝心なことを付け加えるなら、読者の想像力に触れるのに最良の時 期は、彼らがまだ「摇籃」の中にいる時だとされていた。

\section{2 民衆的帝国主義の創出}

教育者が子供の想像力に働きかけるのに、おとぎ話や民話の宝庫を見逃すわけには 行かなかった。明治国家が国内政治における政府の正当性を確立するのに皇国神話を利 用したのと同様、教育機関では、日本全国にわたって南進政策の支持層を形成するため に民話が再利用された。民話は、国民文化の他の領域と同じく、日本の青少年の修養と いう用途に当てることを求められた情報源の一つであった。

室町時代に生まれた桃太郎は、1888年に初めて小学校の教科書の中に登場した ${ }^{9}$ 。教 科書に載って、この物語の標準版が日本中の子供たちに広まった。国家のお墨付きを得 て標準化されたこの『桃太郎』は、明治時代の創作物であるが、それが1945年まで日本の 教科書の中で定番であり続けた。その標準版の桃太郎は次の通りである：田舎に住む老 父と老婆が、川を流机てきた桃の中から赤ん坊の桃太郎を見つけ、桃太郎は大きくなる と、鬼ヶ島征伐の旅に出て、犬、猿、雉という三匹の動物を手下にした。彼は屈強な鬼 の固い守りを打ち破り、宝を手にして意気揚々と自分の村に帰る。『桃太郎』をただ単に 日本帝国の拡張主義的なものとして取り上げるのはフェアではないと思う。しかしなが ら、戦前の教育者も政治家もよく、この一見罪のない物語の中に、帝国主義的な意識を 日本の青少年に植え付けるための絶好の道具を見いだした。敗戦の後、GHQの命令で、 「桃太郎：海の神兵」が焼却されたばかりではなく、戦争プロパガンダに度々使われてい た桃太郎は小学校の教科書から完全に姿を消した。

8 鶴見祐輔『南洋遊記』(大日本雄弁会, 1917), pp.5-6.

9 教科書版の『桃太郎』と大日本帝国の拡張主義とのつながりについて、詳しくはAntoni, Klaus. "Momotarō and the Spirit of Japan : Concerning the Function of a Fairy Tale in Japanese Nationalism in the Early Shōwa Age" in Asian Folklore Studies 50 : 1991, pp.158-165を参照。 
1890年代から既に数多くの作家が、武勇の士の鏡として、また帝国主義国家の象徴と して、桃太郎を描き始めていた。㟲谷小波は、日清戦争の勃発とともに「桃太郎」という 短編を発表した。その短編では、桃太郎は「党莱此日本の菄站の方、海洋遥かに隔てた処

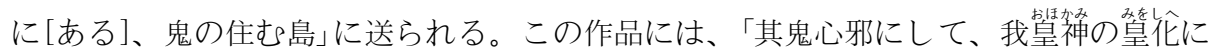

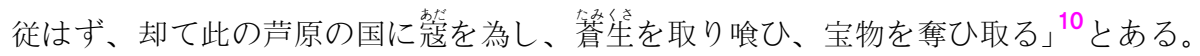
巌谷が鬼を中国の清と同一視したのに対し、他の作家たちは鬼ヶ島のありかを当時の南 洋に求め、桃太郎を帝国主義者として描き始めた。1895年に少年向け雑誌『少年世界』に 掲載された「今桃太郎」では、桃太郎は日本の大将で、鬼ヶ島は当時日本の植民地になっ たばかりの台湾、鬼の宝物は台湾の砂糖きび産業ということになっている ${ }^{11}$ 。1896年 に、「新派演劇の父」と呼ばれている、川上音二郎は、「台湾鬼退治」という芝居を上演 し、話題を集めるようになった。その芝居では桃太郎は台湾総督となり、総督府に反対 している㲖祴と呼ばれている台湾人を征伐する芝居である。

しかしながら有名な作家たちがこの民話と大日本帝国の拡張の間の関わりを示す理論 を発展させたのは、20世紀の最初の 20 年間一清水元のいわゆる南洋熱の時代一なのであ る。この時期以降、桃太郎は青少年が見習うべきお手本となった。桃太郎の鬼が島遠征 は、日本の海外進出、とりわけ南進の比喻と見なされるようになった。

\section{3 新渡戸稲造と桃太郎主義}

1907年、新渡戸稲造(1862-1933年)は、「桃太郎の昔噺」という論文を発表した ${ }^{12}$ 。昔 話は「吾人に精神的の動機を与へ」ることができるのだから、教育者は「祖先伝来に受け て来た吾人の能力と、又た祖先伝来耳にし来つた教訓を次の世代に伝えていかなけれ ばならない。『桃太郎』は子供が初めに聞かされる昔話であり、彼らの「脳裏に印像せら れる」 ${ }^{13}$ 。しかし新渡戸は、この昔話のより広い含意を大人も子供もとらえ損ねている と嘆く。彼は、この物語の中にある重層的な意味一歴史的、道徳的、そして経済的な意 味一を強調し、時代を超えたこの物語が20世紀の青少年に対して特別な関わりを持つのは どのようにしてかを示そうとしている。

桃太郎のモデルが源喣朝で、12世紀に為朝が伊豆諸島に島流しにされた事実に基づい て桃太郎の物語が作られたという滝沢馬琴の仮説に言及する。だが新渡戸はすぐさま、 歴史が「具体的」、「客観的」であるのに対して、昔話は「代表的」、「主観的」だと述べ

10 鳥越信『桃太郎の運命』(ミネルヴァ書房, 2004), p.13での引用。

11 京の葍兵衛「今桃太郎」(下) (『少年世界』第1巻第8号, 1895), pp.816-821.

12 この論文は、「桃太郎遠征譯」というタイトルの講演をもとに書かれたものだが、そこには、桃太郎に対

し、また国民的な意識を高めるために昔話を利用することに対し、新渡戸が長年関心を抱いていたのがよ

く表れていた。

13 新渡戸稲造「桃太郎の昔噺」(『新渡戸稲造全集』第5巻, 教文館, 1969), p.186. 
る ${ }^{14}$ 。そのために、桃太郎は、日本人の現実の歴史ではなく、むしろその前史を発見で きるようなプリズムを与えてくれるのである。桃太郎が典型的な国民の英雄であるのに 対して、新渡戸は逆説的にも、その起源が外国にあることを強調する。桃太郎の名前の 由来である桃の原産地が日本ではないのと同じように、桃太郎は古代にマレ一から日本 に笑挙してやってきた冒険心旺盛な人々のシンボルだというのである。桃太郎の家来の 動物は、彼が征服した先住民族の社会を表している ${ }^{15}$ 。桃太郎が他の民族集団を吸収す る許容力を持つことは、現代の日本民族が多数の異民族を同化する能力を持つことを前 もって示している。又、元々マレ一出身の桃太郎にしてみれば、南洋進出というのは本 能的なもので、ある意味では里帰りだったと記している。

新渡戸は、植民地化を行うに適した民族的な資質を定義するために、『桃太郎』の「歴 史的な」意味を利用するその一方で、次にこの物語の「倫理的な」次元へと話を転じる。 そもそも彼は、「男らしい」桃太郎が少年たちにとっての理想のお手本だと論じている。 新渡戸はしばしば、性的差異の含みのある用語で植民地主義を言い表しており、この用 語法によれば、日本人の植民者が男性で、植民地はこの男性に身を捧げる女性である。 新渡戸はある論文中で次のように書いている。「女子が妙齢になると赤い帯を欲しがる 様に、国家も亦発展すると赤道に領地を得んことを望む様になる」 ${ }^{16}$ 桃太郎が男らしさと リーダーシップを体現するのに対して、彼の家来の動物は、智(猿)、忠実(犬)、勇気 (雉)という儒教道徳を表す。男らしい英雄が鬼退治に成功を収める理由は、これらの徳 を授かっているからである。新渡戸の描く植民者は、日本の辺境に住む「鬼」を、文明化 を要する野蛮人と見なした。植民地の未開人を征服することで、国家は自己統制力があ ることを実証し、帝国主義の世界システムの中で他国を支配する能力を顕示するとされ ていた。

しかも、新渡戸にとって、桃太郎による鬼ヶ島征伐の寓意的な教訓のうちで主要な ものは、「経済的な」意味を持つ。

僕は桃太郎遠征の昔噺を以て、正しく日本国民が海外に意を注いで奮進する精神 を表したものと信ずるのである。而して鬼ケ島とは、南洋諸島の総称である。日本 が僅か八洲に止まつて居た時代は、八丈島が即ち鬼ヶ島で、為朝時代の鬼ケ島は即 ち八丈島であつた。…寧万其後は琉球を以て鬼ヶ島と称へなければなら無くなつ た。されど又た琉球が一旦日本の領地となり、日本語も普及した以上は、モウ一層 南方の島を鬼ヶ島と称すべき事となつた。一歩を南方に進むれば、島猶ほ南に在 り、鬼ヶ島の名称は日本人の南進と共に愈よ南に移り行く。明治二十八年迄は、台湾 が即ち鬼ヶ島であつた。占領後十余年の今日も尚ほ鬼ヶ島のやうな感を以て、内地 人は台湾を見て居る。言語風俗の異なる間は之れも止むを得め、恐らくは今後五年

\footnotetext{
14 新渡戸稲造「桃太郎の昔噺」(『新渡戸稲造全集』第5巻, 教文館, 1969), p.188.

15 上同書, pp.191-192.

16 新渡戸稲造「文明国民南下の大勢」(『新渡戸稲造全集』第四巻, 教文館, 1969), p.471.
} 
乃至十年経つたならば、此の名は当らなくなつて、モウ一層南方の島を鬼ヶ島とし て、今日の桃太郎は遙かに遠き鬼ケ島を指して遠征することになるであらう。又た 鬼ケ島の宝と云ふは、即ち熱帯の物産を指すのであつて、宝は「田から」なり。鬼ヶ 島の宝は即ち熱帯地方の農産物を云つたことで、隠れ㝨、隠れ笠、福桘等を桃太郎が 分捕して来たといふとは、即ち種々産物を本国に供給したことであらう ${ }^{17}$ 。

新渡戸は桃太郎の物語を、日本のマニフェスト・デスティニーの隠喻であると言っ ている。つまり、日本が自己を拡張し、南島を征服し、その宝を奪わずにはいられない 衝動の隠喻と解釈している。日本人の侵略の後それに抵抗して鬼がさらに南に向かって 逃げるせいで、鬼の住む島の位置は時間の経つに従って少しずつ南の方に変わる。新渡 戸は、経済的な解釈に入ると、動物の家来の役割は必要としないのか、家来は話から完 全にいなくなる。新渡戸がこの随筆を書いた時に、日本は既に琉球 (1879年) と台湾 (1895年)を征服して、領土を求めてさらに南に目を向ける。桃太郎による征伐は、絶え ず南進を続ける大日本帝国のアレゴリーとして、世間一般に流布するようになる。

1920年代に国際連盟の長官となった新渡戸は、日本有数の国際主義者として優れた評 判を持つ人物である。と同時に、日本の帝国主義と密接な関わりも持ってもいた。若い 頃の新渡戸は、札幌農学校で農学を学び、北海道とその原住民の植民地化事業に加わっ た。1901年には台湾総督府の民政長官であった後藤新平から、砂糖産業の復興のために 招聘され、砂糖産業はのちに台湾の基幹産業の一つとなり、植民地統治のための主要な 収入源ともなった。新渡戸は、アメリカのジョンズ・ホプキンス大学とドイツのハレ大 学、さらには京都大学で正式に国際政治学を学んだ後、東京帝国大学で新設の植民政策 講座を担当する様になった。東京帝国大学と拓殖大学でこの新たな学問分野の基本的な カリキュラムを作り出し、大日本帝国において重要な役割を担うべき次世代の専門家た ちを育成した。

新渡戸は世界中の植民地制度の体系的な比較研究を行い、この世界的な枠組の内部に 日本の植民地政策を位置づけた。この新たな学問の創立は、新興の大日本帝国を正当化 し、またこの帝国が最新の学問知識に基づいていると示すのに重要な役割を果たし た。この学問の創出が、帝国が国際的な規範の条件に従って建設された証となったの みならず、「日本の帝国を定義する国際的な条件に、権威ある学術的な説明を与えた」 18 のである。

新渡戸は植民地政策についての後期の著作で、帝国のアレゴリーとして桃太郎には限 界があり不完全だとしばしば指摘していた。桃太郎は鬼を征伐するとすぐ日本にある自 分の村に戻り、鬼には自分たちだけで好きにさせる。新渡戸は『桃太郎』を修正して、侵 略者というよりむしろ、長期の定住者として桃太郎を作り変える。侵略者が新たな領土

17 新渡戸稲造「文明国民南下の大勢」(『新渡戸稲造全集』第四巻, 教文館, 1969), p.195.

18 Dudden, Alexis. The Japanese Colonization of Korea. New York: Columbia University Press, 2004. p.132. 
を併合してそこにある資源を領有するのに対し、定住者は植民地にとどまり、その資源 を開発する。新渡戸は桃太郎を自分の理想に近づけるために、話の筋に新しい要素を付 け加えてそれを実質上作り直すことで、もとの話に欠けているものを補うのである。 1916年、新渡戸は次のように書いている。

僕は桃太郎の話が大好きで屡々このお伽彩を繰返したことがある。然るに新日本 のお伽啝としては少しく之に修正が要ると思ふ。即ちその修正といふのは新日本の 桃太郎は須く鬼ケ島に行ったら、その到着地に土着して本国に帰らぬことである。 宝の島に入りて宝を持って帰らぬので、爺婆を鬼ヶ島に呼び寄せ、その国土に於て 己が一家の愉快なる発展を図るのである ${ }^{19}$ 。

『桃太郎』を修正したいという新渡戸の意志は確かに偽りのないものだったが、桃太 郎を平和的な定住者に変えることが本当に可能であっただろうか?

\section{4 芥川龍之介と桃太郎のパロディ}

新渡戸が桃太郎を、若者が見習うべき植民者のお手本と見なしたその一方で、芥川龍 之介は短編小説『桃太郎』で、桃太郎が帝国主義の恐ろしいシンボルだと暴いて見せた。 この小説の初出は1924年7月1日の『サンデー毎日』である。この小説の中で、芥川は桃太 郎というこの理想の少年を 侵略者として風刺し、鬼に平和的な島民の役を当てた。新渡 戸が国定教科書に出てくる標準化された『桃太郎』に基づいてそこから教訓を引き出した のに対して、芥川はおとぎ話に特徵的なスタイル（例えば、「むかし、むかし、大むか し」という決まり文句)をリアリスティックな詳細の描写と組み合わせ、辛辣な批評を用 いて風刺を生み出した。彼は標準版の『桃太郎』をよく知っている大人を読者として想定 し、その物語をまるまる省略した。

この赤児を孕んだ実は深い山の奥を離れた後、どういふ人の手に拾はれたか?それは今更話すまでもあるまい。谷川の末にはお婆さんが一人、日本中の子供の知 つてるる通り、柴刈りに行つた打爺さんの着物か何かを洗つてるたのである。

芥川は桃太朗という主人公を鋭く批判したが、しかし彼は桃太郎を最初に悪者扱いし た思想家では無い。自由主義思想家である福澤諭吉は50年前に『ひら゙のをしへ』(1871)の 中で、桃太郎が青少年の見習うべき人物像としては不適切だと非難していた。「も>た ろふが、おにがしまにゆきしは、たからをとりにゆくといへり。けしからぬことなら

19 新渡戸稲造「大和民族の発展」(1916)(拓殖大学創立百年史編纂室編『新渡戸稲造-国際開発とその教育の先駆 者』(拓殖大学出版会, 2001), p.276.

20 芥川龍之介『芥川龍之介全集』第11巻(岩波書店, 1996)，p.159． 
ずや。たからは、おにのだいじにして、しまいおきしものにて、たからのぬしはおに なり」 ${ }^{21}$ と民族の英雄」として称賛する新渡戸の桃太郎をただの悪者として扱ってい る。福澤は桃太郎が無償で他人のものを自分のものとして、市民社会のモデルには成り 立てないものと思ったのである。それだけでは無く、桃太郎の鬼ヶ島ゆきそのものは ただ鬼の大事にしている宝を奪い取るためだから、桃太郎は悪者、ただの篮”と文言い 切る。

芥川は、それ以前の『桃太郎』文学を参考に、とりわけ嚴谷小波や尾崎紅葉といった有 名な作家の作品を茶化して用いた。芥川は巌谷と同様に、国家の象徴を身につけた桃太 郎(彼は日の丸の扇を持っている)を持ち上げ、彼を天皇制イデオロギーに結びつけた。 また尾崎と同様に、標準版の『桃太郎』の視点を逆にして、鬼の立場から物語を語った。 結局のところ、芥川の語りの斬新さは主として、桃太郎に対する徹底した偶像破壊的な 態度にある。桃太郎が日本国家と同一視されるせいで、作家は読者に、日本の帝国主義 に批判的な見方をして、それを被植民者の視点から考え直すように促すことになる。

芥川は主に話の基本的な要素を逆にすることで、標準版の『桃太郎』をひっくり返し た。物語の老父と老婆が働き者の百姓だとすれば、桃太郎はただの怠け者である。結局 骨の折れる仕事から逃れるために鬼ケ島征伐の旅にでる。「彼はお節さんやお婆さんの やうに、山だの川だの畑だのへ仕事に出るのがいやだつた」22。芥川は桃太郎を急け者 として描くことで、粗忽な南洋島民を勤勉な日本人と対比するという、日本人のよく使 う紋切り型のレトリックを逆転する。対照的に、鬼たちの方が人間らしい社会をなして いる。この小説には、桃太郎が侵略してくる以前に、鬼たちが平和に仲良く楽しく暮ら している様子が描かれている。

鬼ヶ島への旅の途中で、桃太郎は三匹の動物に出会い、うまく口車に乗せて自分の家 来をさせる。この場面で、彼は男性的なリーダーよりも、人を操るのが上手で、悪知恵 を使って他人を自分の思うままにする名人である。例えば自分の㯟団子が「勿論実際は 日本一かどうか、そんなことは彼にも怪しかつたのである」 ${ }^{23}$ と書くが、彼は平気でそ うだと宣伝する。彼はまた抜け目のない商売人で、家来たちが彼のために㗢きたいと申 し出ると、算盤を取り出して懸け引きをする。桃太郎は、自分だけが㯟団子を持ち有利 な立場にあるから、ほうびを㯟団子一個から半分にまけさせる。彼は動物たちから信頼 を得るというより、彼らが腹をすかせているのにつけこむことで、彼らを従える権力 を手に入れる。

三匹の動物は儒教道徳のシンボルだと新戸部は思ったが芥川にしてみれば、動物達 はむしろ仏教の三毒の寓意的な表象である。犬は仁の徳ではなく怒りを表し、小賢しい 猿は貪りを、雉は勇の徳よりむしろ迷妄を表す。その三匹の動物は、お互いを嫌ってい

21 桑原三郎『福澤諭吉と桃太郎 明治の児童文化』(慶應義塾大学出版会, 1996), p.10での引用。

22 上同書, p. 159.

23 上同書, p. 160. 
て絶えず喧嘩する。犬は大きな牙をむき出しにして意気地のない猿を脅し、計算高い猿 は役立たずの雉をひたすら軽藿し、「地震学などにも通じた」 24 雉は頭の鈍い犬を見下し ている。

桃太郎が日本の帝国主義の象徵とすれば、家来の動物たちは、この帝国主義を支える 様々な社会集団、すなわち、戦争を煽る軍部、利益を求める資本家、道を誤った知識人 を表す。犬は軍部の中の拡張主義の支持者たちを表す。これは帝国が新たに獲得した空 間の中で自律的に活動した重要な社会集団で、殊に彼らの活動の舞台となったのが、後 に関東軍が満州事変を画策することになる中国であった。この小説の初期草稿には、 「桃太郎の本国へ帰つた後、鬼が島の知事になったのは武断主義の犬である」といら記述 があり、これはおそらく、日本の植民地を支配したのがすべて武官だったという事実に 言及するものである。犬は知事として、桃太郎の家来の誰にも角がない以上、「今後角 を生やしてるる鬼は死刑に処す」という布告を出す ${ }^{25}$ 。猿に象徵される第二の集団は、 さらなる経済的利権を求めている財閥のことである。猿が鬼ヶ島征伐に行くのをやめそ うになると、桃太郎はこう釘を刺す。「では伴をするな。その代り鬼が島を征伐して も、宝物は一つも分けてやらないぞ」 ${ }^{26}$ 。そのせいで、猿は考え直さざるをえなくな る。最後に、雉は帝国の拡張を要求する知識階級を表している。芥川は、雉が「地震学 などにも通じ」ていたと述べている。この物語が出版されたのは、1923年の関東大震災 の1年後だが、地震学者は誰もこの災害を予知できなかった。日本の民間伝承では、雉 (と锘)の異常行動は地震が差し迫っていることの前兆だと見なされていた。芥川は、自 分の小説に出てくる雉を科学者にすることで、そうした迷信を鼻で笑い、科学としての 地震学の地位を揶揄している27。芥川の風刺においては、これらの様々な集団の正体が 犯罪者の集まりであることが暴露される。彼らの言葉からイデオロギーによる粉飾を剥 ぎ取れば、それは単に略奪を正当化するものにすぎない。

鬼ケ島に着くと動物たちは、本物の怪物に変貌する。桃太郎は片手に桃の旗を持ち、 もう一方の手で日の丸の扇を振りながら、自分の子分たちに略奪・強盗をほしいままに させる。「進め! 進め! 鬼といふ鬼は見つけ次第、一匹も残らず殺してしまへ!」ろく に食べ物も与えられない家来の動物たちは凶暴さをあらわにする。この小説では、鬼の ような悪者はまぎれもなく、桃太郎と彼に加担する三匹の動物である。

しかし、芥川の桃太郎が同時代の植民地主義をパロディにするのに用いているもう 一つの方法はこの小説の舞台である。普通の桃太郎では、鬼は岩だらけの島にある砦で 守りを固めた恐ろしい戦士であるのに対して、芥川の描く鬼は遠い熱帯の島で暮らして おり、自分たちの身を守るすべを持っていない。

\footnotetext{
24 桑原三郎『福澤諭吉と桃太郎 明治の児童文化』(慶應義塾大学出版会, 1996年), p.160. 25 芥川龍之介「「桃太郎」草稿」(『芥川龍之介全集』第21巻, 岩波書店, 1997), p.406.

26 芥川龍之介「桃太郎」(『芥川龍之介全集』第11巻, 岩波書店, 1996), p.161.

27 『桃太郎』における社会風刺の分析としては、Beongchen Yu, Akutagawa：An introduction, Detroit：

Wayne University Press, 1972, pp.52-52を参照。
} 
鬼が島は絶海の孤島だつた。が、世間の思つてるるやうに岩山ばかりだつた訳で はない。実は楖子の䇤えたり、極楽鳥の囀つたりする、美しい天然の楽土だつた。 からいふ楽土に生を享けた鬼は勿論平和を愛してるた。いや、鬼といふものは元来 我々人間よりも享楽的に出来上つた種族らしい。瘤取りの話に出て来る鬼は一晚中踊 りを踊つてるる。一寸法師の話に出て来る鬼も一身の危険を顧みず、物詣での姫君 に見とれてるたらしい28。

芥川は南洋熱の時代にこの物語を書いたので、その舞台を南洋の熱帯の島に設定す る。新渡戸が熱帯の怠け者というステレオタイプを持ち出すのと同様、芥川は楖子の 実、極楽鳥、蘭の花、バナナなどを用いて、鬼ヶ島を熱帯の楽園として描く。酒好きで 色好み、子供のような娛楽を愛する鬼に屈託のない生活を送る。「鬼は熱帯的風景の中 に琴を弾いたり踊りを踊つたり、古代の詩人の詩を歌つたり、頗る安穏に暮らしてる た。その又鬼の妻や娘も機を織つたり、酒を醸したり、蘭の花束を拵へたり、我々人間 の妻や娘と少しも変らずに暮らしてみた。」29芥川のロマンティックな原始主義におい て、鬼は現在の日本人よりも純潔な性格を持ち、遠く隔たって過去の日本人の様なもの である。芥川の中編小説『河童』と同じく、『桃太郎』は、人間に照らし合わせながら鬼を 理想化して描き出すアレゴリーで、鬼が人間社会を批判するために用いられる。新渡戸 の論文に出てくる鬼が、文明を持たない点によって特徴付けられているのとは異なり、 芥川の鬼ケ島の住人たちは心の充足というものを知る。そのような充足を欠いているの はむしろ桃太郎と彼の子分たちであり、だからこそ彼らは強欲で飽くことを知らない。 芥川は、植民地主義への批判を行うために二段構えの技法を用いている。一方で、民話 に出てくる日本の英雄(桃太郎) という人物像の化けの皮を剥ぎ、他方で、鬼の社会を ユートピアとして理想化するのである。理想化された他者は、日本人の欠点と対照をな す引き立て役の働きをする。

植民政策学の教授として、新渡戸は植民地化を文明の普及と日本民族の海外進出と考 えていた。芥川にとって、植民地化は徒労にすぎない。結局のところ、南島の征服に よって桃太郎が得る見返りは少なく、島民たちの利益はさらに少ない。桃太郎は、鬼の 子供に引かせた荷車に一杯の宝を持って、意気揚々とふるさとに帰るが、戦勝の英雄が 期待するような幸福な余生を送るわけではない。人質になった鬼の子供は大きくなる と、桃太郎の番人の雉を殺し、自分の島に逃げ帰る。鬼ヶ島で生き残った鬼は復售に燃 え、海を渡ってやって来て、桃太郎の屋敷を襲い火を放ち、猿を殺した。悪夢のような 出来事が繰り返す中で、桃太郎は忠実な犬にこう言う。

「どうも鬼といふものの執念の深いのには困つたものだ。」 犬も相桘を打つ。

28 芥川龍之介「桃太郎」(『芥川龍之介全集』第11巻, 岩波書店, 1996), p.162. 29 上同。 


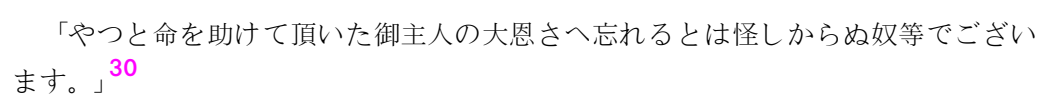

結局、桃太郎は 自分 の行動がどれほど被植民者たちを刺激して、彼らを団結させる ことになるか、全く分かっていない。桃太郎は、自分が傷つけた被害者が征服を歓迎 し、この「大恩」を感じてくれるのではないかと期待していたが、そうでは無く彼らの 「執念深さ」を目の当たりにして嘆いた。だが、芥川が示唆しているように、それはた だ、平和を愛する享楽的な鬼たちが、彼らのユートピアである島が桃太郎の強盗団に破 壊された後に、「復讐に燃えた鬼になるということでしかなかった。

芥川の風刺はまた、桃太郎がはからずも暴力の連鎖を発動させ、それが征服者の打倒 と島の脱植民地化につながるということを示唆してもいる。植民地の征服は、征服され た人々の「民族的な」意識を呼び起こし、独立への欲求を目覚めさせ、彼らを隷属させる 権力に抵抗するよう駆り立てる。鬼の若者は、桃太郎のやり口に学んで、手近にある材 料を使って武器を作り、「独立」のために戦う。

その間も惄しい鬼が島の磯には、美しい熱帯の月明りを浴びた鬼の若者が五六 人、鬼が島の独立を計画する為、楖子の実に爆弾を仕こんでるた。優しい鬼の娘た ちに恋をすることさへ忘れたのか、默々と、しかし嬉しさうに茶碗ほどの目の玉を 浾かせながら、 31

このイメージ一楖子の実をくり抜いて爆弾を仕込む若者の姿一は、植民地の征服が もたらす毒の果実である。この征服のせいで、南の島がもとの熱帯の楽園に戻ることは 不可能で、桃太郎による征伐の結果として、若者は屈託のない生活を捨ててストイック な戦士になってしまう。

芥川にとって、桃太郎の南進は実際には、ありがたいお恵みの仮面をかぶった残忍 な征服と搾取であることが暴かれる。芥川の風刺はつまるところ、民話が両刃の剣であ ることを示す。民話は、新渡戸のような日本の帝国主義のデマゴーグのための武器にも なれば、芥川のような風刺作家の武器にもなる。芥川の小説が出版された後の 20 年間 に、民話「桃太郎」はおびただしい量の絵本や漫画や宝塚歌劇、ポスターや歌やアニメー ションの中に利用された。このようなことが起こる前から、芥川は侵略や戦争を促進 させるために桃太郎の人物像が濫用されるべきではない、とすでに我々に警告してい た。

30 芥川龍之介「桃太郎」(『芥川龍之介全集』第11巻, 岩波書店, 1996), p.165.

31 上同書, p.166. 
参考文献(Bibliography)

芥川龍之介(1996)『芥川龍之介全集』第11巻, 東京：岩波書店. Akutagawa, Ryunosuke (1996) Akutagawa Ryunosuke Zenshu Vol. 11. Tokyo : Iwanamishoten.

芥川龍之介(1997)『芥川龍之介全集』第21巻, 東京：岩波書店. Akutagawa, Ryunosuke (1997) Akutagawa Ryunosuke Zenshu Vol. 21. Tokyo : Iwanamishoten.

京の暮兵衛 (1895)「今桃太郎(下)」『少年世界』第1巻第8号, pp.816-821. Kyouno, Warabe (1895) Konmomotaro (ge). Shounensekai Vol. 1. №. 8, pp.816-821.

桑原三郎 (1996)『福澤諭吉と桃太郎 明治の児童文化』，東京：慶應義塾大学出版会. Kuwahara. Saburou(1996) Hukuzawa Yukichi to Momotarou Meizi no zidoubunnka. Tokyou : Keiogizyukudaigakushuxpannkai.

田山花袋(1973)『田山花袋全集』第一巻, 東京：文泉堂書店. Tayama. Gatai (1973) Tayama Gatai Zenshu Vol. 1. Tokyo : Bunsendoushoten

土屋忍 (2002)「文学における土人：中川陽一と村上龍」川村湊『戦後という制度』，東京：インパクト出版。 Tsuchiya. Sinobu(2002) Bungakuni Okeru Dozin : Nakagawa Yoichi to Murakami Ryu. Kawamura Minato, Sengoto iu Seido. Tokyou : Inbakutoshuxpan.

鶴見祐輔 (1917)『南洋遊記』, 東京：大日本雄弁会講談社. Tsurumi, Yusuke(1917) Nanyouyuki, Tokyo： Dainihonyubenkoudansha.

夏目漱石(1952)『彼岸過迄』, 東京：新潮文庫. Natsume. Souseki(1952) Higansugimade. Tokyo：Shinchoubunko. 新渡戸稲造 (1969)『新渡戸稲造全集』第4巻, 東京：教文館. Nitobe, Inazo(1969) Nitobeinazozenshu, Vol. 4, Tokyo： kyoubunkan.

新渡戸稲造 (1969)『新渡戸稲造全集』第5巻, 東京：教文館. Nitobe, Inazo(1969) Nitobeinazozenshu, Vol. 5, Tokyo： kyoubunkan.

拓殖大学創立百年史編纂室 編 (2001) 『新渡戸稲造 国際開発とその教育の先駆者』, 東京: 拓殖大学出版会. Dakushokudaigakusourichuhyakunensihensansitu hen (2001) Nitobeinazo Kokusaikaihatu to Sono Kyouiku no Senkusha, Tokyo : Dakushokudaigakushuxpankai.

Antoni, Klaus (1991) "Momotarō and the Spirit of Japan : Concerning the Function of a Fairy Tale in Japanese Nationalism in the Early Shōwa Age" in Asian Folklore Studies 50.

Dudden. Alexis (2004) The Japanese Colonization of Korea. New York : Columbia University Press.

Shimizu Hajime (1987) "Nanshin-ron: Its Turning Point in World War I" in The Developing Economies XXV-4. December.

Beongchen Yu(1972) Akutagawa : An introduction, Detroit: Wayne University Press. 